\title{
The Dynamic Capability of the Indonesian General Election Commission (KPU) in the 2020 Election during the COVID-19 Pandemic
}

\author{
Nanang Subekti ${ }^{1 *}$ Ismi Dwi Astuti Nurhaeni ${ }^{2}$ Rina Herlina Hariyanti ${ }^{3}$ \\ ${ }^{1,2,3}$ Faculty of Social and Political Sciences, Universitas Sebelas Maret, Indonesia \\ "Corresponding author.Email:nngsubekti@student.uns.ac.id,nngsubekti@gmail.com
}

\begin{abstract}
:
Background: COVID-19 has brought fundamental changes to various public sectors, one of which is the implementation of the 2020 simultaneous regional head elections in Indonesia. Objectives: The purpose of this article is to analyze the dynamic capabilities of the KPU from a dynamic governance perspective in the implementation of the 2020 elections in Indonesia. Methods: This article uses data sources from the literature review and secondary data related to the organization of Elections in Indonesia which have been published through social media youtube and the official website of the institutions, namely on DPR, KPU, Ministry of Home Affairs, and BNPB accounts during March-August 2020. Result: KPU's dynamic capabilities in organizing the election are shown with the capacity of thinking ahead, thinking again, and thinking across in response to the threat of the Covid-19 pandemic. Thinking ahead can be seen from the KPU's efforts to place the principle of the safety of organizers and voters in the Election to prevent the emergence of new clusters of the spread of Covid-19. Thinking again is shown by reviewing, revising, and making new policies and programs in the implementation of the 2020 elections. Thinking across is shown by the KPU's willingness to learn from other countries having successfully held Pilkada in the era of the Covid-19 pandemic to be used as a basis for policy innovation formulation.
\end{abstract}

Keywords: dynamic capability, KPU, the 2020 elections, the COVID-19 pandemic

\section{INTRODUCTION}

COVID-19 brings so many basic and fast changes. Various forms of adjustment must be made in all aspects of life. This outbreak also raises very basic questions about how strong and compatible are the social, political, economic, and health service systems that have been built so far, at the global, national and subnational levels[1]. As a result, it turned out to have an impact on various sector lines, one of which is the state administration, including the 2020 simultaneous elections. The 2020 election in Indonesia has become the national agenda, the implementation of which was postponed for some time as a result of the COVID-19 Pandemic.

The 2020 elections were held simultaneously to elect the regional head in 270 regions covering 9 provinces and $261 \mathrm{regencies/cities.} \mathrm{The} \mathrm{implementation} \mathrm{of} \mathrm{this} \mathrm{election} \mathrm{is} \mathrm{a}$ manifestation of a democratic country. Regional head elections play a role as a mechanism for political change regarding the pattern and direction of public policies or regarding the periodic and orderly circulation of the elite
[2]. The regional head who acts as the head of the administrative region is the main person responsible for the administration of government in the region elected through democratic elections[3].

The postponed elections in March 2020 have a serious impact on the potential vacancies for future regional leaders. It raises concerns that regional development will be disrupted because postponing elections also means delaying the leadership transformation process. The logical consequence of postponing the elections was that there were vacancies for regional heads in several regions [4].The regional head of the 2020 regional election results is needed to accelerate the handling of COVID-19[5].

Responding to this potential, there was a mutual agreement in May 2020 between the legislative body (DPR), the General Election Commission (KPU), Ministry of Home Affairs to continue the election stage. This agreement demands the KPU's dynamic ability of carrying out the election stages by taking into account the protocol for preventing the spread of COVID-19.The General Election Commission (KPU) offers several options for the implementation of elections to the Government and DPR. 
The first option is a delay of three months from the initial voting schedule, namely 9 December 2020 . This option is taken if the pre-voting Pilkada stages can start at the end of May 2020. The second alternative, the delay is carried out for six months from the initial schedule, which is 17 March 2021. The third option, the elections vote will be postponed for 12 months until 29 September 2021[6].

The Government stipulated Government Regulation in Lieu of Law Number 2 of 2020 as the basis for resuming the election. This regulation provides a legal basis for postponing elections as a result of non-natural disasters in article 201A paragraph (1), as well as regulating the postponed simultaneous voting to be held on December 2020 in article 201A paragraph (2). Then the voting originally to be held on September 23, 2020, was shifted to December 9, 2020.

Few studies have discussed the 2020 elections in Indonesia in the era of the COVID-19 Pandemic. Kennedy \& Suhendro examined the potential consequences of regional head vacancies resulting from a postponement of the election stage[4]. Other research discussed the impact of the COVID-19 pandemic on the implementation of the 2020 election. The presence of COVID-19 can directly prevent voters from casting their votes at polling stations and even affect the overall voter turnout rate, there are consequences of officially postponing the organization of different elections according to regime type (national or local), and some elements in the electoral stage could be affected by the pandemic [7].

This study discusses the 2020 elections in Indonesia from the organization level's view, the KPU, especially related to how the organization adapts to environmental changes in achieving goals. From the perspective of dynamic governance, an organization requires dynamic capabilities to produce adaptive policies. KPU's ability of responding to the dynamics caused by the COVID-19 pandemic is very important to achieve the success of the 2020 elections. This study will enrich knowledge in the field of politics and public policy about how an organization responds to dynamic environmental changes, and how the KPU's ability is to manage election stages in order to produce leaders in regions during a pandemic.

Election during a pandemic has become a new history in the electoral process in Indonesia. The success of implementing simultaneous elections in 2020 will be a reference for the next elections. Based on the background above, this study aims to analyze the dynamic capabilities of the KPU in a dynamic governance perspective on the implementation of the 2020 Election in Indonesia.

\section{LITERATURE REVIEW}

\subsection{Dynamic Governance}

Dynamic governance is simply understood as government activity in the process of implementing public policies by adjusting the results of an analysis of internal and external developments in the institutional environment[8]. Dynamic governance refers to the policymakers' ability of addressing the rapid environmental change issues that require continuous adjustment of policies and programs [9].

Neo and Chen [10] state that dynamism in governance is very important to the sustainable economic and social development in an environment that is uncertain and rapidly changing. Dynamic governance concerns the government's ability to adapt public programs and policies on an ongoing basis so that interests can be achieved [10]. Dynamic governance emphasizes on 2 (two) important keys: capabilities and culture that will drive human resources and processes towards adaptive policy change. In this study, a dynamic governance perspective is relevant for explaining the KPU's capabilities in the dynamics of organizing the 2020 elections amid the COVID-19 pandemic.

\subsection{Dynamic Capabilities}

Dynamic capability is the ability of an organization to create, to expand, or to change its resource base. The concept of dynamic capabilities includes the capacity that can be used to identify needs or opportunities for change, to formulate responses to needs or opportunities, and to carry out an action[11]. Dynamic capabilities provide a mechanism for organizations to adopt, to adapt, or to reconfigure their resource base in response to changing environmental conditions [12]. The component of dynamic capability, according to Neo \& Chen, reflects a mindset of 3 things: thinking ahead, thinking again, and thinking across. The three dynamic capabilities will direct the organization to make adaptive policies [10].

Thinking ahead is the ability to think in formulating future conditions that may have an impact on domestic conditions. This capability is needed to understand the early signals of future developments that can influence a country to keep relevant. This capability is necessary to identify the future environmental developments, to understand their implications, and to identify the options needed to take advantage of new opportunities and to face potential threats. This thought process includes exploring and anticipating future trends and developments that may have a significant impact on policy objectives. Besides, it is necessary to strategize what options can be used to prepare for emerging threats and to take advantage of new opportunities.

Thinking again reflects the ability and openness to reflect on previous policies, then evaluated and refined so that their performance is better for maximizing the achievement of goals. Thinking again is the ability to evaluate the performance of existing strategies, policies, and programs, and then to redesign them to achieve better quality and results. The process of rethinking involves such activities as reviewing and analyzing actual performance data and understanding public feedback and redesigning policies and programs, partially or completely so that their performance can be improved and their goals are better. 
Thinking across is the ability and openness of insight into learning the experiences, ideas, and concepts of other actors. This ability tries to absorb lessons learned from other countries and then to readjusts it with domestic conditions. This capability seeks to find attractive practices beyond the boundaries of why and how outsiders achieve certain policy objectives, and then to transfer creatively that knowledge into tailored programs that can be experimented in local institutional and policy environments. The process of thinking across borders involves finding new and interesting practices to adopt, to apply, and to approach the same problems.

\section{METHODS}

This study used a qualitative method with a case study approach, according to Yin (as quoted by Creswell \& Poth, 2018), involving the study of a case (or cases) within a reallife, contemporary context or setting This case may be a concrete entity, such as an individual, a small group, an organization, or a partnership. At a less concrete level, it may be a community, a relationship, a decision process, or a specific project [13]. Meanwhile, qualitative research is an inquiry process of understanding based on distinct methodological traditions of inquiry that explore a social or human problem. The researcher builds a complex holistic picture, analyzes word, reports detailed views of information, and conducts the study in a natural setting [14]. Qualitative methods are used to construct the 2020 election phenomenon during the COVID-19 pandemic in Indonesia with an organizational level analysis unit, namely the KPU as the election organizer.

Collecting data and information in case of studies, according to Creswell (2013), can be done by conducting interviews with informants, direct field observations, as well as various studying preexisting documents and reports and material in the form of audiovisual materials. [13]. This article used data sources from review documents and audiovisual material during March-August 2020. Document review was conducted by examining and analyzing relevant documents such as books, journal articles, research reports, laws and regulations, and internet sources. Information from audio-visual recordings related to the implementation of the 2020 Election in Indonesia is obtained through social media youtube and the official websites of the institutions, namely the DPR, KPU, Ministry of Home Affairs, and BNPB account.

\section{RESULTS AND DISCUSSIONS}

Despite the pandemic, the KPU must be able to hold transparent and accountable elections. Organizing elections in most of its stages is the activity of gathering people faceto-face, and this kind of activity is contrary to recommended health protocols to maintain distance to prevent the transmission of COVID-19. Without proper steps, the implementation of the Election will threaten the health of the public, whether it is voters, organizers, participants, or other parties involved.

Various new policy breakthroughs and programs show that the KPU has dynamic capabilities. This step is apparently in the mindset of thinking ahead, thinking again, and thinking across to realize the adaptive policies.

\subsection{Thinking Ahead}

The thinking ahead capacity requires sensitivity to environmental issues and developments in the future. This ability can be seen from the KPU's efforts to place the principles of safety of organizers and voters in the election to prevent the emergence of new clusters of the spread of COVID-19.

The ability to think ahead is manifested into several KPU policies. First, to ensure health care for Indonesian citizens who wish to participate as organizers, the KPU entered into a cooperation agreement with the Indonesian health ministry on February 19, 2020. This agreement was implemented even before the announcement of the first case of COVID-19 in Indonesia which was announced on March 2, 2020. The purpose is to ensure that the election administrators have met certain health standards to be declared ready to work. The election organizer must be equipped with occupational safety and health knowledge taking into account the large workload.

Second, the KPU postponed the election stage on March 21, 2020, as a precautionary step to minimize the spread of Covid-19. Some of the postponed stages include: the inauguration of the Voting Committee (PPS) and the working period of the PPS, verification of the support requirements for Individual Candidates, the formation of Voter Data Update Officers, and updating and compiling the voter lists. This policy is outlined in KPU Decree Number 179 / PL.02-Kpt / 01 / KPU / III / 2020 in response to the WHO's statement declaring COVID-19 a global pandemic, the official statement of the President of the Republic of Indonesia stating the spread of COVID-19 as a National Disaster (Non-Natural Disasters) and Decree of the National Agency for Disaster Management (BNPB) regarding the Extension of the Status of Certain Disaster Outbreaks of Corona Virus in Indonesia. The decision to postpone the Election determined by the KPU preceded Presidential Decree Number 12 of 2020 concerning the status of the Non-Natural Disaster of the Spread of Covid-19 as a National Disaster which was set on April 13, 2020.

Third, after the reactivation of the stages on June 15, 2020, the KPU encourages regional election organizers to carry out collaborative agreement activities with the local health officials to ensure that each stage is continued by implementing health protocols to prevent COVID-19 transmission for organizers, participants, voters and other parties involved in the process. The points of cooperation include socialization of health protocols, formulation of technical guidelines for the implementation of the 2020 Election based on health protocols, facilitation of medical tests, support from a health team, and health evaluation for the 2020 election organizing Ad hoc agency. 


\subsection{Thinking Again}

The ability to think again is shown by conducting reviews, revising, and making new policies and programs in the implementation of the 2020 regional head elections. KPU reviews policies are contained in the regulations for implementing the Election that has been previously determined. These regulations include regulations governing the work procedures for election organizers, updating and compiling voter lists, nominations, campaigns, campaign funds, socialization, voter education and public participation, procurement and distribution of election equipment, voting, and counting of votes and recapitulation of vote results.

The ability to think again is manifested in policy by setting guidelines for the implementation of Elections in Non-Natural Disaster Conditions COVID-19 in KPU Regulation Number 6 of 2020 on July 6, 2020. This policy regulates health protocols in each stage of implementation without changing the previously established regulations.

Some of the policies taken include: (a) limiting the number of voters at the poll, from 800 to 500 voters; (b) limiting the age of field officers to a maximum of 50 years; (c) using personal protective equipment; (d) limiting campaigns in the form of general meetings and (e) using information technology at each stage.

\subsection{Thinking Across}

Indonesia is not alone in postponing the elections. A publication from The International Institute for Democracy and Electoral Assistance (International IDEA) states that between 21 February and 7 May 2020, at least 53 countries and territories around the world have decided to postpone national and subnational elections due to COVID-19. Out of these, at least 18 countries and territories have decided to postpone elections and a national referendum[15]. However, some countries insist on the original decision to keep elections on schedule. At least 20 countries and territories have decided to hold national or subnational elections as originally planned though there are concerns related to COVID-19, 9 of these countries have held national elections or referendums.

Thinking across is shown by the KPU's willingness to learn from other countries having successfully held elections in the era of the COVID-19 pandemic to be used as a basis for policy innovation. Several countries inspired that elections could still be held during the Pandemic, which in turn became one of the factors in the resumption of the regional head elections in 270 regions in Indonesia.

The Republic of Korea's experience with holding a vote on April 15, 2020 has attracted the attention of election organizers, election experts, academics, civil society activists, and politicians around the world including Indonesia. By closely observing how the Korean National Election Commission (NEC) conducts elections amid these unique challenges, they hope to learn important lessons from the Korean experience. Some extraordinary steps to minimize the risk of spreading the virus in elections include encouraging early voting through voting from home, ensuring a safe environment for voting, by implementing voting behavior codes, communicating with voters, adapting campaign methods. The number of voters participating is more than $66 \%$ of the 44 million voters and is the highest one since 1992 [16].

Experiences of Germany, the southern state of Bavaria, has resumed city elections on March 15, 2020, even as officials imposed a nationwide lockdown to limit the spread of COVID-19. The number of people filing ballots is more than that in the previous five years, and election officials are using precautions such as protective gloves. Authorities say voters are allowed to bring their pets. Turnout increased by $3 \%$ [17].

Let's see France's experience with holding the first round of local elections on March 15, 2020. The French government has issued a voting process guideline for all polling stations across the country. They asked the public to keep a distance, at least one meter from the person before them at each row. The number of voters is much lower than the previous election.

The experiences of other countries can raise optimism that elections can still be held during a pandemic. Elections in other countries have convinced the KPU and other stakeholders to jointly decide to resume the postponed stage. However, it does not mean that what is done in other countries is fully implemented in Indonesia. As stated by the Chairman of the KPU, Arif Budiman, the experiences of other countries could become experiences in holding the 2020 Election in Indonesia [18]. But fully adopting other countries' policies for Indonesia is not possible due different culture, regulations, situations, and conditions as well as different budget capacities.

\section{CONCLUSIONS}

In a dynamic governance perspective, organizations need dynamic capabilities to realize adaptive policies. The KPU's dynamic capabilities are needed to respond to external changes due to the COVID-19 pandemic through internal adjustments to build a system that implements health protocols to prevent the spread of COVID-19. The dynamic capability of the KPU in the 2020 election during the pandemic is shown by the capacity of thinking ahead, thinking again, and thinking across in responding to the threat of the COVID-19 pandemic.

First, thinking ahead can be seen from the KPU's efforts to put the principle of the safety of organizers, participants, and voters into elections to prevent the emergence of new clusters of the spread of Covid-19. The KPU is thinking ahead to understand how the future of the COVID-19 pandemic will affect the KPU in holding elections and implementing policies to enable organizers and voters to deal with the potential threat of viral infection.

Second, thinking again is shown by conducting reviews, revising, and making new policies and programs in the implementation of the 2020 regional head elections. Changes in the situation as a result of the COVID-19 
pandemic have made policies to implement each stage of Election implementation that was set in the past need to be improved so that they can continue to run without reducing Election quality while ensuring health protection. Policies and programs should then be revised so that they can continue to be effective in achieving their goals.

Third, thinking across is shown by the KPU's willingness to learn from other countries that have successfully held elections in the era of the COVID-19 pandemic to be used as the basis for formulating policy innovations. Adaptive policymaking requires learning and innovation. By thinking across, the KPU is looking for interesting ideas and practices that can be adapted to domestic needs.

The COVID-19 pandemic provides valuable lessons for the KPU, so that it remains to be dynamic capabilities to face uncertain challenges in the future. The author realizes that this study is still not comprehensive. It can be explored in further research regarding the analysis of actors involved in decision making to resume the Election stage, implementing policies health protocol at the Regional KPU level, and also examining how the effect of implementing health protocols on voter participation in the 2020 elections.

\section{REFERENCES}

[1] Wawan Mas'udi and P. S. Winanti, Tata Kelola Penangan Covid-19 di Indonesia: Kajian Awal. Yogyakarta: Universitas Gadjah Mada Press, 2020.

[2] J. R. A. Sandi and Suprayitno, "Fenomena Pengawasan Pemilihan Kepala Daerah di Kalimantan Tengah Masa Pandemi Covid-19," J. Polit. Pemerintah. Dharma Praja, vol. 13, no. 1, pp. 1-13, 2020.

[3] A. Sulaeman, "Demokrasi, Partai Politik Dan Pemilihan Kepala Daerah," CosmoGov, vol. 1, no. 1, p. $12,2017$.

[4] R. Kennedy and B. P. Suhendarto, "Diskursus Hukum: Alternatif Pola Pengisian Jabatan Kepala Daerah di Masa Pandemi," J. Pembang. Huk. Indones., vol. 2, no. 2, pp. 188-204, 2020.

[5] R. Kartikaningrum, "Kepala Daerah Hasil Pilkada 2020 Mendatang Dibutuhkan untuk Percepatan Penanganan COVID-19," www.bnpb.go.id, 2020. [Online]. Available: https://bnpb.go.id/berita/kepaladaerah-hasil-pilkada-2020-mendatang-dibutuhkan-untukpercepatan-penanganan-covid19. [Accessed: 20-Jul2020].

[6] F. C. Farisa, "KPU Akan Simulasikan Tiga Opsi Penundaan Pilkada 2020 Artikel ini telah tayang di Kompas.com dengan judul 'KPU Akan Simulasikan Tiga Opsi Penundaan Pilkada 2020,"' www.kompas.com, 2020. [Online]. Available: https://nasional.kompas.com/read/2020/04/02/18462391/ kpu-akan-simulasikan-tiga-opsi-penundaan-pilkada2020? page=all. [Accessed: 15-Jul-2020].

[7] R. Rosanti, "Pandemic At the Polls: How To Prepare the Elections Post Covid-19 (Towards Indonesia Local Elections in 2020)," J. Acad. Praja, vol. 3, no. 2, pp. 147-167, 2020.

[8] E. H. Pajri, "Analisi Dampak pelayanan Publik Dalam Perspektif Dynamic Governance (Studi Tentang Kapabilitas Dinamika Kantor Imigrasi Kelas I Khusus Surabaya Dalam Penyelenggaraan Pelayanan Paspor)," $J$. Adm. Negara, UNAIR, 2018.

[9] M. Rask, S. Mačiukaitè-Žvinienè, and L. Tauginienè, Innovative Public Engagement. 2016.

[10] B. S. Neo and G. Chen, Dynamic Governance: Embedding Culture, Capabilities, and Change in Singapore. Singapore: World Scientific Publishing, 2007.

[11] C. E. Helfat et al., Dynamic capabilities and organizational process. 2007.

[12] A. L. Pablo, T. Reay, J. R. Dewald, and A. L. Casebeer, "Identifying, enabling, and managing dynamic capabilities in the public sector," J. Manag. Stud., vol. 44, no. 5, pp. 687-708, 2007.

[13] J. Creswell and C. Poth, Qualitative Inquiry Research Design. California: Sage Publication, 2018.

[14] Creswell JW, Research Design Qualitative, Quantitative, and Mixed Method Approaches by John W. Creswell (z-lib.org).pdf, 4th ed. California: SAGE Publications, 2013.

[15] I. Idea, "Ikhtisar Global COVID-19: Dampak terhadap Pemilu," vol. 19, pp. 1-17, 2020.

[16] A. Spinelli, "Managing Elections under the COVID-19 Pandemic: The Republic of Korea's Crucial Test," Manag. Elections under COVID-19 Pandemic Repub. Korea's Crucial Test, no. April, pp. 1-8, 2020.

[17] Euronews with AP/AFP, “Germany: Bavaria's municipal elections go ahead despite coronavirus concerns," www.euronews.com, 2020. [Online]. Available:

https://www.euronews.com/2020/03/15/germanybavaria-s-municipal-elections-go-ahead-despitecoronavirus-concerns. [Accessed: 21-Jul-2020].

[18] B. Mufarida, "Ketua KPU: Sejumlah Negara Laksanakan Pemilu di Tengah Pandemi Corona," www.kompas.com, 2020. [Online]. Available: https://nasional.sindonews.com/read/91682/12/ketuakpu-sejumlah-negara-laksanakan-pemilu-di-tengahpandemi-corona-1594012034. [Accessed: 15-Jul-2020]. 